\title{
Al-Chizan
}

Jurnal Pemikiran Hukum Islam

ISSN 1907-0985, E ISSN 2442-8256

Vol. 13 , No. 2, 2017, h. $185-203$

DOI: https://doi.org/10.30603/am.v13i2.876

History of Renewal of Islamic Family Law in Indonesia

Nurhikmah Hairak H. Biga

Fakultas Syariah IAIN Sultan Amai Gorontalo

Email: hikmah2939@gmail.com

Abstract: Indonesian family law is the translation of family law in Islam. One problem that is regulated is the issue of marriage law. This marriage law in its development experienced a long journey in formation. In the history of the renewal of Islamic marriage law in Indonesia, there are three periods, namely the period before the arrival of colonialists, colonialism and independence. The independence period was divided into three periods, namely the old order, the new order and the reform period. During the old order, Law Number 22 Year 1946 and Law Number 32 of 1954 were born. In the New Order, Law Number 1 Year 1974 and Presidential Instruction Number 1 of 1991 were born regarding the Compilation of Islamic Law. During the Reformation, the Government and the Gender Mainstreaming Team designed a revised draft on Compilation of Islamic Law.

Keywords: Renewal, Family, Islamic Law, Marriage

\section{Sejarah Pembaruan Hukum Keluarga Islam Di Indonesia}

Abstrak: Hukum keluarga Indonesia merupakan penjabaran hukum keluarga dalam Islam. Salah satu persoalan yang diatur adalah persoalan undangundang perkawinan. Undang-Undang Perkawinan ini dalam perkembangannya mengalami perjalanan panjang dalam pembentukan. Dalam sejarah pembaruan hukum perkawinan Islam Indonesia, ada tiga periodisasi, yakni masa sebelum Indonesia kedatangan Penjajah, masa penjajahan dan masa kemerdekaan. Masa kemerdekaan dibagi menjadi tiga periodisasi, yaitu masa orde lama, orde baru dan masa reformasi. Pada masa orde lama, lahir Undang-Undang Nomor 22 Tahun 1946 dan UndangUndang Nomor 32 Tahun 1954. Pada masa Orde Baru, lahir Undang-Undang Nomor 1 Tahun 1974 dan Instruksi Presiden Nomor 1 Tahun 1991 tentang Kompilasi Hukum Islam. Pada Masa Reformasi, Pemerintah dan Tim Pengarusutamaan Gender telah merancang draft revisi terhadap KHI.

Kata Kunci: Pembaharuan, Keluarga, Hukum Islam, Perkawinan 
Sejarah Pembaharuan Hukum Keluarga Islam di Indonesia

\section{A. Pendahuluan}

Sistem hukum apapun dan di manapun di dunia ini, hukum mengalami perubahan dan pembaharuan. Bagi hukum tanpa kitab suci atau hukum wadh'i, perubahan atau pembaharuan hukum itu dilakukan untuk menyesuaikan hukum dengan perkembangan sosial dan kebutuhan masyarakat. Ini tentu terkait dengan sifat dasar dan ruang lingkup hukum (wadh'i) itu sendiri, yaitu aturan yang dibuat oleh manusia untuk mengatur hubungan hidup antara manusia dengan manusia serta penguasa dalam masyarakat.

Pembaharuan hukum karenanya merupakan keharusan sejarah karena fenomena sosial kemasyarakatan tidaklah statis atau tetap, melainkan selalu berubah. Selain bersifat permanen, hukum juga berubah. Hukum selain bersifat statis dan tetap, pada saat yang sama juga berubah dan diperbaharui agar sesuai dengan perkembangan dan kebutuhan masyarakat.

Gerakan mendobrak taklid dan menghidupkan kembali ijtihad untuk mengembangkan hukum Islam disebut gerakan pembaharuan hukum Islam, sebab gerakan itu muncul untuk menetapkan ketentuan hukum yang mampu menjawab permasalahan dan perkembangan baru yang ditimbulkan oleh kemajuan ilmu pengetahuan dan teknologi modern. Menetapkan ketentuan hukum yang mampu menjawab permasalahan dan perkembangan baru itu mengandung dua unsur. Pertama, menetapkan hukum terhadap masalahmasalah baru yang belum ada ketentuan hukumnya, seperti masalah bayi tabung. Kedua, menetapkan atau mencari ketentuan hukum baru bagi sesuatu masalah yang sudah ada ketentuan hukumnya tetapi tidak sesuai lagi dengan keadaan dan kemaslahatan manusia masa sekarang.

Bentuk pembaruan dapat dikelompokkan menjadi dua, yakni: Pertama, umumnya (mayoritas negara melakukan pembaruan dalam bentuk Undang-undang. Kedua, usaha pembaruan lahir dalam bentuk ketetapan hakim. Perlu ditambahkan, ada pula negara yang melakukan pembaruan dengan berdasar pada dekrit (raja atau presiden). Tujuan pembaruan Hukum Keluarga Islam secara umum ada tiga, yaitu: Pertama, unifikasi hukum perkawinan.; Kedua, peningkatan status wanita; Ketiga, respon terhadap dan menyesuaikan dengan perkembangan dan tuntutan zaman. ${ }^{1}$

${ }^{1}$ Khoiruddin Nasution, Pengantar dan Pemikiran Hukum Keluarga (Perdata) Islam Indonesia (Yogyakarta: ACAdeMIA+TAZAFFA, 2010), 40. 
Pembaruan hukum Islam dalam berbagai aspek sudah terjadi dalam kurun waktu yang lama, berproses dengan kondisi dan situasi perkembangan zaman. Hal ini disebabkan karena hukum-hukum yang terkandung dalam kitab-kitab fikih klasik sudah tidak mampu lagi mengakomodir persoalan-persoalan baru yang berkembang dalam hukum keluarga.

\section{B. Pembaruan Hukum Keluarga Islam di Indonesia}

Hukum Islam masuk ke Indonesia bersamaan dengan masuknya agama Islam yang dibawa oleh saudagar Muslim dari Timur Tengah pada abad ke-7 M. Sebelum Islam masuk ke Indonesia, hukum yang berlaku adalah hukum adat masing-masing yang sangat majemuk, disamping pengaruh agama Hindu yang sangat kuat tertanam di Jawa. ${ }^{2}$

Dalam sejarah pembaruan hukum perkawinan Islam Indonesia, ada tiga periodisasi, yakni masa sebelum Indonesia kedatangan Penjajah, masa penjajahan dan masa kemerdekaan, di mana masa kemerdekaan dibagi menjadi tiga periodisasi, yaitu masa orde lama, orde baru dan masa reformasi.

\section{Sebelum Penjajahan Belanda}

Sejak Islam datang ke Indonesia, ada orang-orang khusus yang dipercayai dan diserahi tugas mengurus masjid dan perkawinan. Ketika terjadi persengketaan dikalangan muslim, termasuk masalah perkawinan dan perceraian, peradilan agama muncul dalam bentuk tahkim yang pengangkatannya oleh para pihak yang bersengketa. Apapun keputusan yang akan dijatuhkan oleh orang yang ditunjuk itu keduanya harus taat mematuhinya. Bertaahkim seperti ini dapat juga dilaksanakan dalam hal selain sengketa, seperti penyerahan pelaksanaan akad nikah dari wanita yang tidak mempunyai wali. Lembaga tahkim ini berlaku ketika masyarakat memeluk Islam secara sendiri-sendiri, artinya belum terbentuk sebagai pranata masyarakat yang teratur dan sistematis.

Kemudian berlanjut dengan masyarakat yang sudah teratur tetapi belum mempunyai pemerintahan. Lembaga peradilannya adalah lembaga ahl al-hall wa al-'aqdi yang oleh Abdul Manan memberikan definisi, yaitu pemimpin masyarakat yang diikuti dan dipercayai oleh umat, dapat

\footnotetext{
${ }^{2}$ Alaidin Koto, Sejarah Peradilan Islam (Jakarta: Rajawali Press, 2011), 192.
} 
Sejarah Pembaharuan Hukum Keluarga Islam di Indonesia

diteriman oleh semua pihak dengan ikhlas hati, penuh istiqamah, bertakwa. Adil, bijaksana serta memiliki semangat untuk bekerja demi kepentingan umum. ${ }^{3}$ Pengangkatan untuk menjadi pelaksana kekuasaan kehakimanan yakni dengan mengangkat orang-orang ahli hukum Islam oleh masyarakat dalam bentuk peradilan Adat, di mana para hakim/qadi diangkat oleh Rapat Marga, Negeri dan semacamnya. Lembaga ini kemudian dilanjutkan dengan lembaga Peradilan Surambi. Peradilan ini dibentuk setelah terbentuk kerajaan-kerajaan Islam di Nusantara. Peradilan Surambi menangani masalah-masalah yang berkaitan dengan kehidupan masyarakat, seperti perkawinan, wasiat, warisan, hibah dan sebagainya. Lembaga ini tidak secara langsung berada di bawah raja, tetapi dipimpin oleh Ulama. Dinamakan Pengadilan Surambi karena diselenggarakan di Serambi Masjid Agung. Keputusan Pengadilan Surambi berfungsi sebagai nasehat bagi Sultan dalam mengambil keputusan. ${ }^{4}$ Setelah keluarnya Undang-Undang Nomor 23 Tahun 1947 tentang Penghapusan Pengadilan Raja (Zelfbestuursrechtspraak), ${ }^{5}$ maka secara yuridis-formal Pengadilan Surambi tidak berfungsi lagi dan melebur ke dalam Pengadilan Agama.

2. Masa Penjajahan Belanda

Ketika Kolonial Belanda mulai memasuki Indonesia melalui VOC, (Verenigde Oostindische Compagnie) atau Perusahaan Hindia Timur Belanda, yakni sebuah wadah dagang yang telah mengarahkan sasarannya untuk menjajah Nusantara, tak dapat menyepelekan eksistensi Hukum Islam yang telah berurat-berakar dilaksanakan oleh masyarakat Islam Indonesia.

Upaya penghapusan Hukum Islam hanya mampu pada bidang hukum pidana. Dengan mengadakan aturan pemisahan antara peradilan keduniawian (werdwldijke rechstpraak) yang dilakukan oleh Pengadilan Gubermen dengan Peradilan Agama. Sementara itu untuk hukum perdata, karena telah mapan dilaksanakan, maka tetap dibiarkan hidup dan berjalan sendiri ditangani oleh Peradilan Agama. Walaupun tetap diintervensi oleh pemerintah Belanda.

Di masa tersebut, hukum perkawinan yang berlaku adalah Compendium Freijer, yaitu kitab hukum yang berisi aturan-aturan hukum perkawinan dan hukum waris menurut Islam. Kitab ini ditetapkan pada

\footnotetext{
${ }^{3}$ Alaidin Koto, Sejarah Peradilan Islam, 194

${ }^{4}$ Alaidin Koto, Sejarah Peradilan Islam, 201.

${ }^{5}$ http://hukum.unsrat.ac.id/uu/uu1947_23.pdf, diakses tanggal 07 Oktober 2018.
} 
tanggal 25 Mei 1760 untuk dipakai oleh Pengadilan Persatuan Kompeni Belanda di Hindia Timur (VOC). Atas usul Residen Cirebon, Mr. P.C Hasselaar (1757-1765) dibuat kitab Tjicebonshe Rechtsboek. Sementara untuk Landraad (sekarang Pengadilan Umum). Di Semarang tahun 1750 dibuat Compendium tersendiri. Sedang untuk daerah Makassar oleh VOC disahkan suatu Compendium sendiri. Keberadaan dan berlakunya Compendium ini diperkuat dengan surat VOC tahun 1808, yang isinya memerintahkan agar para penghulu Islam harus dibiarkan mengurus sendiri perkara-perkara perkawinan dan warisan.

Walaupun kelihatannya Pemerintah Hindia Belanda memberikan jaminan kebebasan untuk penerapan hukum Islam di Indonesia, tetapi pemerintah Hindia Belanda tetap mengintervensi hukum Islam. Terjadinya pengebirian terhadap hukum Islam ini dipengaruhi oleh perpindahan kekuasaan dari VOC kepada pemerintah Hindia Belanda.

Ada beberapa perbedaan pendapat tentang kapan tepatnya Pemerintah Hindia Belanda mulia mengintervensi hukum Islam. Ada yang menyebut sejak lahirnya Stbl 1820 Nomor 24 pasal 13 yang diperjelas dalam Stbl 1835 Nomor $58 .{ }^{6}$

Atas usul Mr. Lodewyk Willem Christian Van Den Berg (1845-1927) berdasarkan teorinya receptio in complexu, yaitu suatu faham yang mengatakan bahwa bagi orang Indonesia mengikuti agamanya, ${ }^{7}$ pada akhirnya pemerintah Hindia Belanda memberikan aturan secara formal dalam perundang-undangan yang lebih konkrit atas pelaksanaan Hukum Islam. Hal ini diwujudkan dengan Stbl 1882 Nomor $52^{8}$ tentang

\footnotetext{
6“'Apabila terjadi sengketa antara orang-orang Jawa satu sama lain mengenai soalsoal perkawinan, pembagian harta dan sengketa-sengketa yang sejenis yang harus diputus menurut Hukum Islam, maka pendeta memberi putusan tetapi gugatan untuk mendapat pembayaran yang timbul dari keputusan pada pendeta itu harus diajukan kepada pengadilanpengadilan biasa."

${ }^{7}$ Sayuti Thalib, Receptio a Contrario (Jakarta:Bina Aksara, t.th.), 5.

${ }^{8}$ Stlb 1882 Nomor 152 berisi tujuh pasal yang maksudnya sebagai berikut:

Pasal 1: Disamping setiap Landraad (pengadilan negeri) di Jawa dan Madura diadakan satu pengadilan Agama, yang wilayah hukumnya sama dengan wilayah hukum Landraad.

Pasal 2: Pengadilan Agama terdiri atas: penghulu yang diperbantukan kepada Landraad sebagai ketua. Sekurang-kurangnya tiga dan sebanyak-banyaknya delapan orang ulama Islam sebagai anggota. Mereka diangkat dan diberhentikan oleh Gubernur/Residen.
} 
Sejarah Pembaharuan Hukum Keluarga Islam di Indonesia

Pembentukan Peradilan Agama di Jawa dan Madura dengan nama Priesterrad?. Sedangkan untuk daerah luar Jawa dan Madura diserahkan kepada peraturan-peraturan Adat maupun Swapraja.

Berbeda dengan L.W.C Van Den Berg, penganut dan pencetus teori receptio in complexu adalah Christian Snouck Hurgronje (1857-1936). Ia merupakan salah satu ahli hukum ada, mencetuskan teori baru yang bertentangan dengan teori L.W.C. Van Den Berg. Teori C. Snouck Hurgronye tersebut dikenal dengan teori receptie, yakni teori yang mempunyai jalan pikiran bahwa sebenarnya yang sangat berlaku di Indonesia adalah hukum adat asli. Ke dalam hukum adat ini memang telah masuk pengaruh hukum Islam. Pengaruh hukum Islam itu, baru mempunyai kekuatan kalau dikehendaki dan diterima oleh hukum adat dan dengan demikian lahirlah ia sebagai hukum Adat bukan hukum Islam. ${ }^{10}$

Berdasarkan teorinya ini, maka C. Snouck Hurgronye menduduki jabatan penasehat Pemerintah Hindia Belanda tentang soal-soal Islam dan anak negeri, menganggap bahwa keluarnya Stbl 1882 Nomor 152 merupakan kesalahan yang patut disesalkan. Sebab, Peradilan Agama ini seharusnya dibiarkan terus berjalan secara liar tanpa campur tangan pemerintah

Pasal 3: Pengadilan Agama tidak boleh menjatuhkan putusan, kecuali dihadiri oleh sekurang-kurangnya tiga orang anggota, termasuk ketua. Kalau suara sama banyak, maka suara ketua yang menentukan.

Pasal 4: Keputusan Pengadilan Agama dituliskan dengan disertai alasan-alasan yang singkat, juga harus diberi tanggal dan ditandatangani oleh para anggota yang turut memberi keputusan. Dalam berperkara itu disebutkan pula jumlah ongkos yang dibebankan kepada pihak-pihak yang berperkara.

Pasal 5: Kepada pihak-pihak yang berperkara harus diberikan salinan surat keput usan yang ditandatangani oleh ketua

Pasal 6 : Keputusan pengadilan agama harus dimuat dalam suatu daftar yang harus diserahkan kepada Residen setiap tiga bulan sekali untuk memperoleh penyaksian dan pengukuhan

Pasal 7: Keputusan pengadilan agama yang melampaui batas wewenang/ kekuasaannya atau tida memenuhi ketentuan ayat (2), (3), dan (4) di atas tidak dapat dinyatakan berlaku.

${ }^{9}$ Pengadilan Agama yang disamakan sebutannya oleh Kolonial Belanda dengan Pengadilan Pendeta

${ }^{10}$ Sayuti Thalib, Receptio a Contrario, 13. 
sehingga keputusan-keputusannya tidak perlu memperoleh kekuatan undang-undang. ${ }^{11}$

Atas desakan dan pengaruh C. Snouck Hurgronye dalam kedudukannya tersebut, secara sistematis, halus dan berangsur-angsur, hukum yang berlaku bagi orang Islam mulai diubah dan dipersempit ruang geraknya dalam kehidupan masyarakat sehingga menimbulkan banyak reaksi dan kekecewaan pada benak masyarakat Islam. Kenyataan tersebut diatas seperti halnya perubahan ketentuan pasal 134 I.S (Indische Staatsregeling) 1925 (yang bunyinya sama dengan ketentuan Pasal 178 RR 1907 dan RR 1919 dulu) yang antara lain bunyi ayat (2) nya: "Kalau terjadi perselisihan perdata antara sesama penduduk inlander atau penduduk yang dipersamakan dengan mereka, diputus oleh kepala agama atau kepala adat mereka menurut undang-undang agamanya atau adat aslinya". Diubah menjadi: "dalam hal terjadi perkara perdata antara sesama orang Islam akan diselesaikan oleh Hakim Agama Islam apabila hukum adat menghendaki dan sejauh tidak ditentukan dengan suatu ordonansi."

Perubahan ini terjadi pada tahun 1929, berdasarkan Stbl 1929 Nomor 221 dengan demikian berarti hukum Islam telah dicabut dari lingkungan tata hukum Hindia Belanda. Pengebirian ini berlanjut dengan lahirnya Stbl 1931 Nomor 53 terjadi pengurangan kompetensi bagi Pengadilan Agama yang hanya mengenai sengketa di bidang nikah, talak, rujuk, perceraian dan halhal lain yang berhubungan dengan itu seperti mahar dan nafkah isteri. Sedangkan untuk bidang hadlanah, waris, wakaf dan lain-lain dicabut dan selanjutnya diserahkan kepada landraat. Meskipun Stbl 1931 Nomor 53 tidak sempat diberlakukan oleh pemerintah Kolonial Belanda, namun mengeluarkan ordonantie baru berupa Stbl 1937 Nomor 116 yang diberlakukan mulai tanggal 1 april 1937 tentang perubahan dan penambahan atas Stbl 1882 Nomor 152. Pemberlakuan Stbl 1937 Nomor 116 yang mencabut kewenangan Pengadilan Agama atas perkara waris menimbulkan protes keras dari Masyarakat Islam. Tetapi tidak ditanggapi oleh Pemerintah Hindia Belanda. Di bulan juli 1937, Pemerintah mengedarkan Rancangan ordononansi Perkawinan Tercatat yang diantara isinya menganut prinsip monogami serta tidak boleh menjatuhkan talak diluar pengadilan. Rancangan ini mendapat respon negatif dari kelompok muslim.

\footnotetext{
${ }^{11}$ Zaini Ahmad Noeh dan Abdul Basith Adnan, Sejarah Singkat Peadilan Agama di Indonesia (Surabaya:Bina Ilmu, 1983), 34.
} 
Sejarah Pembaharuan Hukum Keluarga Islam di Indonesia

Pada masa kekuasaan Belanda, perkawinan diatur dalam beberapa peraturan menurut golongannya, yaitu:

a. Bagi orang-orang Eropa berlaku Kitab Undang-Undang Hukum Perdata (Burgelijk Wetboek BW)

b. Bagi orang-orang Tionghoa, secara umum juga berlaku BW dengan sedikit pengecualian yakni hal-hal yang berhubungan dengan pencatatan jiwa dan acara sebelum perkawinan.

c. Bagi orang Arab dan Timur Asing yang bukan Tionghoa berlaku hukum adat mereka.

d. Bagi orang Indonesia asli berlaku hukum mereka ditambah untuk orang Kristen berlaku undang-undang Perkawinan Kristen Jawa, Minahasa, Ambon (Huwelijk Ordonantie Christen Indonesiers Java, Minahasa an Amboina (HOCI)) berdasar Stbl. No 74 Tahun 1933.

e. Bagi yang tidak menggunakan salah satunya berlaku peraturan Perkawinan Campuran.

Melihat perbedaan dan pengelompokan di atas, tidak ada aturan khusus bagi orang-orang Islam Indonesia. Kesimpulannya, sebelum Belanda datang ke Indonesia, hukum yang berlaku di Indonesia adalah hukum Islam. Ketika VOC berkuasa, hukum Islam masih diakui. Tapi setelah penyerahan kekuasaan kepada pemerintah Hindia Belanda, islam mulai termaginalisasi dan hanya mengatur hal-hal yang sangat terbatas.

3. Masa Kemerdekaan

Sejarah Pembaruan Hukum Islam di masa kemerdekaan dibagi menjadi tiga periode yakni masa orde lama, yaitu selama masa kekuasaan presiden pertama Indonesia, Ir. Soekarno, yang kedua masa orde baru, yaitu masa kekuasaan presiden kedua Indonesia, Jenderal Soeharto dan ketiga masa reformasi, yaitu sejak jatuhnya Jenderal Soeharto.

a. Masa Orde Lama

Undang-undang perkawinan yang lahir setelah Indonesia merdeka pada masa orde lama adalah Undang-Undang Nomor 22 Tahun 1946. Undang-Undang ini sebagai pengganti dari Stbl. Huwelijksordonnantie S. 1929 No. 348 jo. S. 1931 No. 467 dan Vorstenlandsche Huwelijksordonnantie S. 1933 No. 98. "'Undang-undang Pentjatatan nikah,

12“" bahwa peraturan pentjatatan nikah, talak dan rudjuk seperti jang diatur didalam Huwelijksordonnantie S. 1929 Nomor 348 jo. S. 1931 Nomor 467. Vorstenlandsche 
talak dan rudjuk (Undang-Undang Nomor 22 Tahun 1946). Undang-Undang ini dimaksudkan untuk dijalankan diseluruh Indonesia; akan tetapi sebelum keadaan mengizinkannya serta undang-undang baru itu belum berlaku, peraturan yang lama masih dianggap sah. Waktu berlakunya "Undangundang pencatatan nikah, talak dan rujuk" untuk tanah Djawa dan Madura ditetapkan oleh Menteri Agama, sedang di daerah-daerah di luar tanah Jawa dan Madura akan ditentukan oleh Undang-Undang lain. ${ }^{13}$

Undang-undang ini diperluas wilayah berlakunya untuk seluruh Indonesia dengan Undang-Undang Nomor 32 Tahun 1954. Ada tiga tahapan pemberlakuan Undang-Undang Nomor 22 tahun 1946 yakni: Pertama, pada tanggal 1 Februari 1947 berlaku Undang-Undang Nomor 22 Tahun 1946 bagi Jawa dan Madura, berdasar Penetapan Menteri Agama tanggal 21 Januari 1947. Kedua, bagi Sumatera mulai berlaku tanggal 16 Juni 1949 berdasar ketetapan Pemerintah Darurat Republik Indonesia tanggal 14 Juni 1949, Nomor: 1/PDRI/KA. Ketiga, bagi wilayah-wilayah lainnya tanggal 2 November 1954, berdasar Undang-Undang No. 32 Tahun 1954 tanggal 26 Oktober 1954.

Secara garis besar, Undang-Undang Nomor 22 Tahun 1946 terdiri dari 7 pasal yang secara umum hanya memuat dua hal yaitu peraturan tentang pencatatan perkawinan, perceraian dan rujuk serta penetapan pegawai yang ditugasi melakukan pencatatan perkawinan, perceraian dan rujuk.

Selain Undang-Undang Nomor 22 Tahun 1946, kebijaksanaan lain di awal kemerdekaan RI adalah adanya Penetapan Nomor 5 tanggal 26 Maret 1946 tentang perpindahan Mahkamah Islam Tinggi yang sebelumnya berada di Departemen Kehakiman dialihkan kepada Departemen Agama. Demikian juga Maklumat Pemerintah No. II tanggal 23 April 1946 kewenangan mengangkat Penghulu Ladraad, Penghulu Anggota Raad Agama, dan pejabat lain yang dahulu pada Residen dan Bupati diserahkan kepada Menteri Agama.

Tidak banyak Undang-Undang yang lahir pada Masa Orde Lama. Tetapi, Undang-Undang yang lahir di masa orde baru merupakan kelanjutan

Huwelijksordonnantie S 1933 Nomor 98 dan Huwelijksordonnantie Buitengewesten S. 1932 Nomor 482 tidak sesuai lagi dengan keadaan pada masa sekarang, sehingga perlu diadakan peraturan baru jang sempurna dan memenuhi sjarat keadilan sosial." Lihat http://hukum.unsrat.ac.id/uu/uu_22_1946.pdf, diakses tanggal 07 Oktober 2018.

${ }^{13} \mathrm{http}$ ://hukum.unsrat.ac.id/uu/uu_22_1946.pdf, diakses tanggal 07 Oktober 2018. 
Sejarah Pembaharuan Hukum Keluarga Islam di Indonesia

dan respon dari tuntutan yang muncul di masa orde lama. Undang-Undang Nomor 1 Tahun 1974 adalah Undang-Undang pertama yang berisi materi perkawinan. Masyarakat telah lama menginginkan adanya Undang-Undang yang mengatur tentang perkawinan. Keinginan ini tercermin dalam tuntutan beberapa organisasi, khususnya organisasi wanita yang sampai membicarakannya di dewan rakyat.

b. Masa Orde Baru

Perundang-udangan yang lahir di masa orde baru merupakan kelanjutasn dari usaha di masa orde lama. Sebagaimana dicatata sebelumnya, pada tahun 1966 Majelis Permusyawaratan Rakyat Sementara (MPRS) dengan ketetapan No. XXVIII/MPRS/1966 menyatakan dalam pasal 1 ayat (3) bahwa perlu segera diadakan undang-undang tentang perkawinan. Sebagai respon terhadap TAP MPRS tersebut, pada tahun 1967 dan 1968 pemerintah menyampaikan dua RUU kepada DPRGR yaitu: RUU tentang Pernikahan Ummat Islam dan RUU tentang Pokok Perkawinan. Kedua RUU ini dibicarakan oleh DPRGR yang akhirnya tidak mendapat persetujuan berdasarkan keputusan 5 Januari 1968. Alasan tidak dapat disahkannya RUU terebut adalah karena salah satu fraksi menolak, dan dua fraksi abstain, meskipun 13 fraksi dapat menerimanya.

Di awal tahun 1967 pemerintah (ketika itu Menteri Agama KH. Moh. Dahlan) menyampaikan kembali Rancangan Undang-Undang (RUU) Pernikahan Umat Islam untuk dibahas di dewan. Dalam waktu yang hampir sama Dewan Kehakiman menyusun RUU tentang Pekawinan bersifat Nasional dan berjiwa Pancasila dan disampaikan ke DPR (September 1967), dengan maksud RUU dari Departemen Kehakiman sebagai RUU pokok dan dari Departemen Agama sebagai RUU pelaksana. Rancangan ini kembali gagal disahkan karena anggota DPR tidak bergairah membahas. Alasannya karena penyusunannya didasarkan pada perbedaan pandangan.

Beberapa organisasi dalam masyarakat tetap menginginkan, bahkan mendesak pemerintah untuk kembali mengajukan RUU tentang perkawinan, antara lain oleh Ikatan Sarjana Wanita Indonesia (ISWI) dan Badan Musyawarah Organisasi-Organisasi Islam Wanita Indonesia. Tanggal 31 Juli 1973 pemenrintah menyiapkan tentang perkawinan yang baru kepada DPR yang terdiri dari 15 bab dan 73 pasal. RUU ini mempunyai tiga tujuan. Pertama, memberikan kepastian hukum bagi masalah-masalah perkawinan, sebab sebelum adanya undang-undang perkawinan hanya bersifat jugde 
made law. Kedua,melindungi hak-hak kaum perempuan. Ketiga, menciptakan Undang-Undang yang sesuai dengan tuntutan zaman.

Hasil akhir yang disahkan DPR terdiri dari 14 bab yang dibagi dalam 67 pasal. Ada beberapa tanggapan negatif terhadap Undang-Undang Nomor 1 Tahun 1974 ini diantaranya tentang poligami dari Sarekat Istri Jakarta. Dalam pembahasan RUU di DPR sejumlah respon negatif muncul, baik melalui perseorangan maupun organisasi. Diantaranya pandangan Asmah Sjahroni, Wakil Ketua Fraksi Persatuan Pembangunan yang menyebut RUU tersebut menjadi indikasi pencabutan Hukum Perkawinan Adat dan Hukum Perkawinan Islam. Undang-Undang Perkawinan dianggap dan dituduh oleh sebagian masyarakat sebagai usaha sekularisasi yang bertentangan dengan ajaran islam. Rancangan pasal-pasal yang dianggap mendapat kritik paling keras dari kaum Muslim Indonesia di antaranya adalah:

1. Rancangan aturan pencatatan perkawinan sebagai syarat sah perkawinan

2. Bahwa poligami harus mendapatkan izin dari pengadilan

3. Pembatasan usia minimal boleh menikah 21 tahun untuk laki-laki dan 18 tahun untuk perempuan

4. Perkawinan antara pemeluk agama

5. Pertunangan

6. Perceraian harus dengan izin pengadilan

7. Pengangkatan anak

Aturan ini dianggap bertentangan dengan ajaran Islam sebab menurut masyarakat, pernikahan adalah satu ikatan yang sakral dan penuh nuansa agama. UU ini berlaku secara efektif sejak tanggal 1 Oktober 1975 terdiri dari 14 bab dan 67 pasal.

Tahun 1991, berhasil disusun Kompilasi Hukum Islam mengenai Perkawinan, pewarisan dan perwakafan. Kompilasi ini berlaku dengan instruksi presiden No.1 Tahun 1991 tanggal 10 Juni 1991 yang kemudian diikuti dengan keluarnya Keputusan Menteri Agama RI Nomor 154 Tahun 1991 tentang Pelaksanaan Instruksi Presiden RI Nomor 1 Tahun 1991 tersebut. Selanjutnya KHI ini disebarluaskan kepada semua Ketua Pengadilan Tinggi Agama dan Ketua Pengadilan Agama melalui Surat Edaran Direktur Pembinaan Badan Peradilan Agama Islam tanggal 25 Juli 1991 Nomor 3694/EV/HK.003/AZ/91. ${ }^{14}$

\footnotetext{
${ }^{14}$ Abdurrahman, Kompilasi Hukum Islam di Indonesia (Jakarta: Akademika
} Pressindo 1992), 50. 
Sejarah Pembaharuan Hukum Keluarga Islam di Indonesia

Empat jalur pengumpulan data bagi penyusunan tiga kitab hukum itu yaitu; Jalur kitab-kitab fikih, jalur wawancara denga ulama, jalur yurisprudensi peradilan agama dan jalur studi perbandingan. ${ }^{15}$

Lahirnya KHI adalah satu kebutuhan untuk mengakhiri ketidakpastian hukum oleh para Hakim di Pengadilan Agama. Beberapa keputusan hakim di Pengadilan Agama dalam kasus yang sama tetapi mempunyai keputusan yang berbeda. Ini terjadi karena rujukan hukum yang berbeda dimana para hakim menggunakan puluhan kitab fikih. Dalam Konsideran KHI disebutkan bahwa KHI dapat dijadikan sebagai pedoman dalam menyelesaikan masalah dibidang tersebut baik oleh Instansi Pemerintah maupun masyarakat.

Bustanul Arifin berpendapat bahwa tujuan pokok lahrinya Kompilasi Hukum Islam Indonesia adalah untuk unifikasi hukum. Penetapan KHI ini diilhami oleh fakta sejara Muslim yang telah mencoba beberapa kali melahirkan unifikasi hukum Islam. Terbukti pada masa Khalifah Umar Ibn Abd Al-Aziz terjadi unifikasi hukum Islam pertama kalinya.

Fungsi KHI dapat dilihat dari dua sudut pandang. Pertama, dari sudut pandang hukum material, bahwa KHI dapat berfungsi sebagai hukum material di bidang perkawinan, warisan dan wakaf di samping UndangUndang Nomor 1 Tahun 1974 untuk perkawinan dan Peraturan Pemerintah Nomor 28 Tahun 1977 untuk wakaf. Kedua, dari sudut unifikasi hukum, bahwa lahirnya KHI dapat menjadi kitab hukum yang dapat mengakhiri berbagai ragam sumber hukum Islam.

Kritik yang muncul selanjutnya terhadap keberadaan KHI adalah dari tinjauan teori dan tata urutan Perundang-undangan Indonesia. KHI ditetapkan berdasarkan Instruksi Presiden. Dari sisi kekuatan hukum dan urutan perundang-undangan, Instruksi Presiden berada pada urutan ketujuh. Karena itu KHI mempunyai kekuatan hukum yang lemah. Menurut A. Hamid S. Attamimi bahwa ada interpretasi lain terhadap status instruksi presiden, bukan hanya interpretasi yang mutlak dan absolut. Dengan demikian, dasar pemberlakuan KHI yang hanya instruksi Presiden berdasarkan interpretasi ini tidak perlu dipermasalahkan.

c. Masa Reformasi

${ }^{15}$ Bustanul Arifin, Pelembagaan Hukum Islam di Indonesia Akar Sejarah, Hambatan dan Prospeknya (Jakarta: Gema Insani Press 1966), 59-60. 
Maksud masa reformasi di sini adalah sejak jatuhnya rezim Orde Baru pada bulan Mei 1998 hingga saat ini. Hal ini berarti berada dalam lima masa presiden, yaitu (1) Prof. Dr. Ir. B. J. Habibie, (2) K.H. Abdurrahman Wahid (3) Megawati Soekarno Putri (4) Susilo Bambang Yudhoyono (5) Periode kedua Susilo Bambang Yudhoyono.

Isu yang muncul pada masa reformasi ini adalah usulan mencabut Peraturan Pemerintah Nomor 10 Tahun 1983 yang mengatur tentang izin perkawinan dan perceraian bagi Pegawai Negeri Sipil (PNS). Perkawinan yang dimaksud dalam PP ini adalah perkawinan poligami. ${ }^{16}$ Usulan pencabutan ini mencuat di tahun 1999 oleh Wanita Muslimat Partai Bulan Bintang yang menginginkan diberlakukannya poligami tanpa membatasi dengan ketat. Tapi usulan ini tidak mendapat respon positif dari masyarakat Indonesia.

Di tahun 2000, isu ini mencuat kembali setelah ada pernyataan dari Menteri Negara Pemberdayaan Perempuan pada Masa K. H. Abdurrahman Wahid, Khofifah Indar Parawansah bahwa Peraturan Pemerintah Nomor 10 Tahun 1983 seharusnya dicabut karena masalah poligami menyangkut persoalan pribadi yang tidak perlu diatur negara. Respon masyarakat beragam. Ada yang setuju dengan usulan tersebut namun banyak yang menolak.

Di penghujung tahun 2006, muncul usulan agar Peraturan Pemerintah Nomor 1983 diperluas pemberlakuannya, yaitu kepada seluruh warga negara Indonesia, bukan hanya PNS dan yang dipersamakan dengannya. Tetapi usulan ini semakin hari semakin meredup sampai akhirnya tidak diperbincangkan lagi.

Di tahun 2006 juga lahir Undang-Undang Nomor 3 Tahun 2006 sebagai amandemen terhadap Undang-Undang Nomor 7 Tahun 1989. Undang-undang ini memberikan otoritas dan status yang lebih luas lagi kepada Pengadilan Agama. Disebutkan dalam Undang-Undang Nomor 7 Tahun 1989 pasal 49 bahwa: "Pengadilan Agama bertugas dan berwenang memeriksa, memutus, dan menyelesaikan perkara-perkara di tingkat pertama antara orang-orang yang beragama Islam di bidang: perkawinan; kewarisan,

\footnotetext{
${ }^{16}$ PP No. 10 Tahun 1983 ini ditahun 1990 terjadi beberapa perubahan yang di atur dalam PP. No. 45 tahun1990 yang diantaranya melarang Pegawai Negeri Sipil (PNS) wanita untuk menjadi istri kedua/ketiga/keempat yang dalam PP. No. 10 tahun 1983 diperbolehkan dengan syarat izin dari pejabat.
} 
Sejarah Pembaharuan Hukum Keluarga Islam di Indonesia

wasiat, dan hibah, yang dilakukan berdasarkan hukum Islam; wakaf dan shadaqah.” Dalam pasal 49 Undang-Undang Nomor 3 tahun 2006 sebagai amandemen dari UU No. 7 tahun 1989 disebutkan bahwa: Pengadilan agama bertugas dan berwenang memeriksa, memutus, dan menyelesaikan perkara di tingkat pertama antara orang-orang yang beragama Islam di bidang: perkawinan; harta; wasiat; hibah; wakaf; zakat; infaq; shadaqah; dan ekonomi syari'ah."

Seiring dengan mencuatnya perdebatan masa Peraturan Pemerintah Nomor 10 Tahun 1983, isu merevisi isi Undang-Undang Nomor 1 Tahun 1974 dan Kompilasi Hukum Islam sebagai Undang-Undang pokok perkawinan pun ikut mendapat perhatian. Departemen Agama R.I telah berhasil menyusun draft (rancangan) revisi terhadap KHI. Draft ini kelak akan menjadi hukum material di Peradilan Agama di bidang perkawinan. Rancangan ini berjumlah 23 bab dan 150 pasal.

Di samping itu, ada pula draft yang merupakan hasil kajian dan penelitian Tim Pengarusutamaan Gender (PUG) Departemen Agama R.I terhadap Kompilasi Hukum Islam Indonesia. Draft PUG kemudian terkenal dengan Counter Legal Draft (CLD) Kompilasi Hukum Islam. Buku I tentang Perkawinan Islam mencakup 116 pasal, kedua tentang Hukum Kewarisan Islam mencakup 8 bab dan 42 pasal dan buku ketiga tentang perwakafan mencakup 5 bab 20 pasal. Rumusan yang digunakan CLD KHI berdasarkan maqasid al-syari'ah yakni menegakkan nilai prinsip keadilan sosial, kemaslahatan umat manusia, kerahmatan semesta dan kearifan lokal, dengan menggunakan empat pendekatan utama, yaitu; gender, pluralisme, HAM dan demokrasi. Rumusan ini bahkan telah dipublikasikan pada bulan september 2004. Banyak ulama yang mengecam draf ini. Sebagian ulama telah menghitung tidak kurang dari 39 kesalahan dalam CLD KHI dan sebagian lain mengalkulasi minimal terdapat 19 kesalahan. Karena itu menurut ulam ini, CLD KHI harus segera dicabut dari peredaran agar tidak membingungkan dan semakin meresakan masyarakat. Bahkan tim CLD KHI menurut para ulama ini, menciptkana syariat islam baru, sesuatu yang seharusnya tidak dilakukan manusia karena hak dan wewenang menciptakan syariah sepenuhnya ditangan Allah swt. Dengan alasan ini, menteri agama turun tangan membatalkan CLD KHI.

Ada tiga alasan yang mendasari mengapa revisi terhadap KHI merupakan agenda mendesak diselenggarakan. Yang pertama bahwa KHI memiliki kelemahan pokok justru pada rumusan visi dan misinya. Beberapa 
pasal didalamnya bertolak belakang dengan prinsip dasar Islam seperti yang banyak diungkap secara literal oleh Al-Qur'an, yaitu prinsip persamaan (almusawah), persaudaraan (al-ikha), keadilan (al-'adl), kemaslahatan, penegakan HAM, pluralisme (al-ta'addudiyah) dan kesetaraan jender. Kedua, KHI tidak paralel dengan produk undang-undang baik hukum nasional maupun internasional yang telah diratifikasi. Bangunan epistimologi yang digunakan tim CLD KHI dalam merumuskan konsep yang ditawarkan adalah mengungkap dan merevitalisasi kaidah ushul marjinal yang tidak terliput secara memadai dalam sejumlah kitab ushul fikih dan membongkar bangunan paradigma ushul fikih lama.

Pada tanggal 27 Februari 2012, pembaruan hukum terjadi dalam undang-undang hukum perkawinan. Terkait dengan adanya permohonan yudisial review yang diajukan oleh Aisyah Mokhtar dan anaknya yang bernama Muhammad Iqbal Ramadhan bin Moerdiono terhadap ketentuan Pasal 2 ayat (2) dan Pasal 43 ayat (1) Undang-Undang Nomor 1 Tahun 1974 tentang Perkawinan, di mana Moerdiono sebagai seorang suami yang telah beristri menikah kembali dengan istrinya yang kedua bernama Aisyah Mokhtar secara syari'at Islam dengan tanpa dicatatkan dalam register Akta Nikah, oleh karena itu ia tidak memiliki Buku Kutipan Akta Nikah, dan dari pernikahan tersebut lahir seorang anak laki-laki yang bernama Muhammad Iqbal Ramdhan Bin Moerdiono.

Dengan berlakunya Pasal 2 ayat (2) dan Pasal 43 ayat (1)) UndangUndang Nomor 1 Tahun 1974 tersebut Aisyah Mokhtar dan Muhammad Iqbal Ramdhan hak-hak konstitusinya sebagai warga negara Indonesia yang dijamin oleh Pasal 28 B ayat (1) dan ayat (2) serta Pasal 28 D ayat (1) UUD 1945 telah dirugikan, karena status perkawinannya menjadi tidak sah, ${ }^{17}$ demikian juga terhadap anak yang dilahirkannya menjadi tidak sah. Dan berakibat hilangnya status perkawinan antara Moerdiono dengan Aisyah serta status Muhammad Iqbal Ramdhan sebagai anak Moerdiono Pasal 2 ayat (1) Undang-Undang Nomor 1 Tahun 1974 menyatakan "perkawinan

${ }^{17}$ A. Mukti Arto, Diskusi Hukum Putusan Mahkamah Konstitusi RI Nomor 46/PUU-IIIV/2010 Tanggal 27 Pebruari 2012 Tentang Perubahan Pasal 43 UUP, (Bahan Diskusi Hukum Hakim PTA Ambon dan PA Ambon Bersama Pejabat Kepanitreaan pada tangal 16 Maret 2012 di Auditorium PTA Ambon). Lihat Syamsul Anwar Dan Isak Munawar, "Nasab Anak Di Luar Perkawinan Paska Putusan Mahkamah Konstitusi Nomor 46/Puu-Iiiv/2010 Tanggal 27 Pebruari 2012 Menurut Teori Fikih Dan PerundangUndangan," dalam https://www.academia.edu/5461536/ ARTIKEL_NASAB_ANAK_ DI_LUAR_PERKAWINAN, diakses 07 Oktober 2018, 1. 
Sejarah Pembaharuan Hukum Keluarga Islam di Indonesia

adalah sah apabila dilakukan menurut hukum masing-masing agamanya dan kepercayaannya itu" ayat (2)-nya menyatakan "tiap-tiap perkawinan dicatat menurut peraturan perundang-undangan yang berlaku. Pasal 43 ayat (1) Undang-Undang Perkawinan menyatakan "anak yang dilahirkan di luar perkawinan hanya mempunyai hubungan perdata dengan ibunya dan keluarga ibunya". Undang-Undang Dasar RI 1945 Pasal 28 B ayat (1) yang menyatakan "setiap orang berhak membentuk keluarga dan melanjutkan keturunan melalui perkawinan yang sah", Pasal 28 B ayat (2) menyatakan bahwa "setiap anak berhak atas kelangsungan hidup, tumbuh dan berkembang serta berhak atas perlindungan dari kekerasan dan diskriminasi", dan Pasal 28 D ayat (1) yang menyatakan "setiap orang berhak atas pengakuan, jaminan, perlindungan dan kepastian hukum yang adil serta perlakuan yang sama di hadapan hukum".

Atas permohonan tersebut Mahkamah Konstitusi berpendapat mengenai ketentuan Pasal 2 ayat (2) UU Nomor 1 Tahun 1974 tentang pencatatan perkawinan bahwa sesuai penjelasan umum angka 4 huruf b UU Nomor 1 Tahun 1974 Mahkamah Konstitusi menyimpulkan (1) pencatatan perkawinan bukan faktor yang menentukan sahnya perkawinan (2) pencatatan merupakan kewajiban administrasi yang diwajibkan berdasarkan perundang-undangan. Kewajiban-kewajiban administrasi tersebut dapat dilihat dari dua prespektif, yaitu ; pertama dari prespektif negara, pencatatan dimaksud diwajibkan dalam rangka memenuhi fungsi negara untuk memberikan jaminan perlindungan, pemajuan, penegakan dan pemenuhan hak-hak asasi manusia yang bersangkutan yang merupakan tanggung jawab negara dan harus dilakukan sesuai prinsif negara hukum sebagaimana yang dimuat pada Pasal 281 ayat 4 dan ayat (5) UUD 1945. Sekiranya pencatatan tersebut dianggap pembatasan, maka pembatasan yang demikian tidak bertentangan dengan ketentuan konstitusi karena pembatasan dimaksud semata-mata untuk menjamin pengakuan serta penghormatan atas hak dan kebebasan orang lain. Kedua pencatatan secara administratif yang dilakukan oleh negara dimaksudkan agar perkawinan sebagai perbuatan hukum penting yang berimplikasi terjadinya akibat hukum yang sangat luas, dan dikemudian hari perkawinan itu dapat dibuktikan dengan bukti yang sempurna dengan suatu akta autentik. Oleh karena itu Mahkamah Konstitusi berpendapat bahwa Pasal 2 ayat (2) UU Nomor 1 Tahun 1974 tidak bertentangan dengan konstitusi Mahkamah Konstitusi berpendapat mengenai anak yang dilahirkan di luar perkawinan yang dikonklusikan dengan anak yang tidak sah. Menurut Mahkamah Konstitusi secara alamiah 
tidak mungkin seorang perempuan hamil tanpa terjadinya pertemuan antara ovum dengan spermatozoa baik melalui hubungan seksual maupun melalui cara lain berdasarkan perkembangan teknologi yang menyebabkan terjadinya pembuahan. Oleh karena itu tidak tepat dan tidak adil manakala hukum menetapkan bahwa anak yang lahir dari suatu kehamilan karena hubungan seksual di luar perkawinan hanya memiliki hubungan dengan perempuan tersebut sebagai ibunya. Adalah tidak tepat dan tidak adil pula jika hukum membebaskan laki-laki yang melakukan hubungan seksual yang menyebabkan terjadi kehamilan dan kelahiran anak tersebut dari tanggung jawabnya sebagai seorang bapak. Akibat hukum dari peristiwa hukum kelahiran karena kehamilan yang didahului dengan hubungan seksual antara seorang perempuan dengan seorang laki-laki adalah hubungan hukum yang didalamnya terdapat hak dan kewajiban secara bertimbal balik yang subjek hukumnya adalah anak, ibu dan bapak. Dengan demikian hubungan anak dengan seorang laki-laki sebagai bapak tidak semata-mata karena adanya ikatan perkawinan akan tetapi dapat juga didasarkan pada pembuktian adanya hubungan darah antara anak dengan laki-laki tersebut sebagai bapak. Kemudian Mahkamah Konstitusi menyimpulkan bahwa Pasal 43 ayat (1) tersebut bertentangan dengan Undang-Undang Dasar 19457 Oleh karena itu Mahkamah Konstitusi mengabulkan permohonan pemohon dengan salah satu diktumnya me-review ketentuan Pasal 43 ayat (1) tersebut menjadi "anak yang dilahirkan diluar perkawinan mempunyai hubungan perdata dengan ibunya dan keluarga ibunya serta dengan laki-laki sebagai ayahnya yang dapat dibuktikan berdasarkan ilmu pengetahuan dan teknologi dan/atau alat bukti lain menurut hukum mempunyai hubungan darah, termasuk hubungan perdata dengan keluarga ayahnya". Putusan Mahkamah Konstitusi tersebut adalah suatu putusan final yang berkaitan dengan uji materil undang-undang, yang dalam hal ini Pasal 43 ayat (1) Undang-Undang Nomor 1 Tahun 1974. Oleh karena itu Putusan MK ini berlaku sebagai undang-undang sehingga substansinya general, tidak individual dan tidak kasuistik sesuai ketentuan Pasal 56 ayat ((3) jo Pasal 57 ayat (1) UUMK. Oleh karena itu pula putusan Mahkamah Konstitusi ini menjadi norma hukum yang berlaku untuk seluruh warga negara Indonesia tentang hubungan hukum antara anak dengan kedua orang tuannya beserta segala konsekwensinya, baik anak itu adalah anak yang dilahirkan oleh seorang perempuan yang dihamili seorang laki-laki tanpa ikatan perkawinan (anak zina), dan setelah anak itu lahir kedua orang perempuan dan laki-laki ini tidak pernah mengikatkan diri dalam ikatan perkawinan yang sah maupun 
Sejarah Pembaharuan Hukum Keluarga Islam di Indonesia

setelah anak tersebut lahir kemudian kedua orang perempuan dan laki-laki itu mengikatkan diri dalam ikatan perkawinan yang sah (anak di luar perkawinan), atau anak tersebut lahir dari seorang perempuan yang dihamili seorang laki-laki dalam ikatan perkawinan yang tidak memiliki kepastian dan tidak memiliki kekuatan hukum, karena peristiwa perkawinannya tidak sesuai dengan perundang-undangan yang berlaku (perkawinan siri atau perkawinan di bawah tangan). ${ }^{18}$

\section{Penutup}

Sejak abad ke VII M ketika Islam masuk ke Indonesia, Hukum Islam telah berlaku di Indonesia. Lembaga peradilan di zaman sebelum penjajahan yang pertama adalah tahkim kemudian berlanjut pada lembaga ahl al-hall wa-al'aqdi kemudian dilanjutkan dengan Lembaga Swapraja dan akhirnya Pengadilan Agama yang bertahan hingga saat ini.

Di awal penjajahan Belanda di Indonesia, hukum islam di akui dan di gunakan oleh masyarakat pemeluk agama Islam. Setelah VOC mengalami kemunduran dan kekuasaan berpindah tangan ke pemerintah Hindia Belanda, penjajah mulai mengebiri hukum Islam dengan membatasi ruang gerak peradilan Agama.

Pada masa orde lama, lahir Undang-Undang Nomor 22 Tahun 1946 untuk menggantikan materi hukum yang ditinggalkan oleh Belanda yang berlaku untuk masyarakat di pulau Jawa dan Madura. Perluasan wilayah untuk pemberlakuan Undang-Undang Nomor 22 Tahun 1946 untuk seluruh wilayah di Indonesia diatur dalam Undang-Undang Nomor 32 Tahun 1954.

Pada masa Orde Baru, lahir Undang-Undang Nomor 1 Tahun 1974 sebagai hukum material di bidang perkawinan, warisan dan wakaf. Lalu pada tahun 1991 lahir Kompilasi Hukum Islam yang merupakan Instruksi Presiden dengan tujuan penetapan KHI untuk menjadi pegangan Hakim.

Pada Masa Reformasi, muncul isu untuk pencabutan Peraturan Pemerintah Nomor 10 Tahun 1983 tentang izin poligami dan perceraian bagi PNS, dan hingga saat ini Undang-Undang tersebut masih berlaku. Di

${ }^{18}$ Syamsul Anwar dan Isak Munawar, "Nasab Anak Di Luar Perkawinan Paska Putusan Mahkamah Konstitusi Nomor 46/Puu-Iiiv/2010 Tanggal 27 Pebruari 2012 Menurut Teori Fikih dan Perundang-Undangan," dalam https://www.academia.edu/5461536/ ARTIKEL_NASAB_ANAK_DI_LUAR_PERKAWINAN, diakses 07 Oktober 2018, 4-5. 
samping itu, Kementerian Agama RI (dulu Departemen Agama RI) berhasil merancang draft revisi terhadap KHI dan Tim Pengarusutamaan Gender juga menghasilkan draft yang merupakan hasil penelitian dan kajian terhadap Kompilasi Hukum Islam.

\section{DAFTAR PUSTAKA}

Abdurrahman. Kompilasi Hukum Islam di Indonesia. Jakarta: Akademika Pressindo 1992.

Anwar Syamsul, dan Isak Munawar, "Nasab Anak Di Luar Perkawinan Paska Putusan Mahkamah Konstitusi Nomor 46/Puu-Iiiv/2010 Tanggal 27 Pebruari 2012 Menurut Teori Fikih Dan PerundangUndangan," dalam https://www.academia.edu/5461536/ ARTIKEL_ NASAB_ANAK_DI_LUAR_PERKAWINAN

Arifin, Bustanul. Pelembagaan Hukum Islam di Indonesia Akar Sejarah, Hambatan dan Prospeknya. Jakarta: Gema Insani Press 1966.

Koto, Alaidin. Sejarah Peradilan Islam. Jakarta: Rajawali Press, 2011.

Nasution, Khoiruddin. Pengantar dan Pemikiran Hukum Keluarga (Perdata) Islam Indonesia. Yogyakarta: ACAdeMIA+TAZAFFA, 2010.

Noeh, Zaini Ahmad, dan Abdul Basith Adnan, Sejarah Singkat Peadilan Agama di Indonesia. Surabaya: Bina Ilmu, 1983.

Thalib, Sayuti. Receptio a Contrario. Jakarta:Bina Aksara, t.th.

http://hukum.unsrat.ac.id/uu/uu_22_1946.pdf

http://hukum.unsrat.ac.id/uu/uu1947_23.pdf. 